\title{
Trust Giving Transactions on Mu'amalah Al-Wadi'ah
}

(Study of Thematic Interpretation Approaches to the Word Al-Wadiah in the Qur'an)

\author{
Saiful Bahri, Syarkawi, Mursal, Fizazuawi1, Maimun \\ State Islamic Institute (IAI) of Al-Aziziyah Samalanga, Indonesia \\ tgkdrsaiful@gmail.com
}

\begin{abstract}
The practice of mu'amalah al-Wadi'ah in Indonesian is often termed by liter literary savings, which is currently underway among the people through Bakn Syari'ah institution. Definition of wadi'ah, even though there is a diversity of editors in the formulation of the meaning, but substantially does not show fundamental differences, it's just that there are editorial differences between including and representing. So it can be understood that wadi'ah is giving power to someone who is trusted to maintain certain assets in a certain way. The legal basis for Wadiah is found in Qur'an, Surat al-Nisa verse: 58, and Surat alBaqarah, verse: 283. Besides that, there is also a legal basis in the hadith, a History of the abi of David, and the ijmak of the scholars.
\end{abstract}

Keywords : Al Quran; muamalah; Islamic economy law

\section{Introduction}

In the view of Islam, the creation of humans as inhabitants of this world aims to carry out duties or the obligation of worship is one very essential thing. In the explanation can be detailed (devotion to God which is termed ibadah mahdhah worship, and related to the rights and obligations of fellow human beings termed ibadah ghayru mahdhah worship). In the present context, your relationship with the community with Islamic banks, for example, is in carrying out its operations with the Islamic legal system (sharia), accepting deposits, lending money and other financial services. Islamic banks use Islamic principles in their operations, namely by using the principle of al Ta'awun which implements a system of mutual assistance and cooperation between community members in goodness (QS. Al Maidah: 2) and the principle of avoiding Al Ikthina such as leaving money idle and not spinning in transactions that benefit the general public.

In the practice of everything in the form of al-Wadi'ah or other Islam explicitly still forbids the existence of gharar (the element of uncertainty or trickery in transactions), maysir (the existence of gambling elements whose transactions are speculative which can cause losses to one party and profits for others), Riba (forms of transactions that use the interest system) ${ }^{1}$.. On the human side, as social beings, they cannot live independently without assistance or in contact with other individual, this is clearly due to a person's limitations in fulfilling their daily needs. So in that case Islam has provided guidance and rules for humans in living life in this world. As for one of the ease of Islamic teachings is the existence of one form of mu'amalah from the activities of relations between humans known as al-Wadiah. AlWadi'ah is a form of reciprocal relations in order to provide assistance between human beings by way of giving the mandate of an item from one party to another so that the mandate is maintained in accordance with the guidelines set in Islam.

The practice of mu'amalah al-Wadi'ah in Indonesian is often termed by liter literary savings, which is currently underway among the people through Bakn Syari'ah institution. In the historical literature the establishment of Shari'ah banking as an institution that promotes

\footnotetext{
${ }^{1}$ Muhammad Syafi'I Antonio, Bank Syari'ah, dari teori ke Praktek, Jakarta, Gema Insani Press, 2001, p. 146.
} 
mu'amalah al-Wadiah has become one of the facilities of the Islamic ummah in infesting funds as well as a more systematic storage in terms of material security. The main objective of the establishment of financial institutions is that the efforts of the Islamic ummah in particular can underlie the practice of mu'amalah in growing its economic growth in accordance with the Qur'an and Sunnah. It was stated that Syari'ah Bank first appeared in 1963 as a pilot project in the form of a rural savings bank in the small town of Mit Ghamr, Egypt. The next experiment took place in Pakistan in 1965 in the form of a cooperative.

\section{Review of Literature}

\subsection{Definition of al-Wadi'ah}

In the language of al-Wadi'ah comes from the word al-iida', which means representing others to take care of something voluntarily. Etymologically al-Wadi'ah is from the word wadda'a al-syai'a which means leaving something. So it's called wadiah because he was left in the place of the person who was entrusted. In syara 'wadi'ah is the name for the treasure that is entrusted to someone who keeps it without payment ${ }^{2}$ Ibn Hajar al-Haitamy, In the book of tuhfah al-muhtaj explaining al-wadi'ah is:

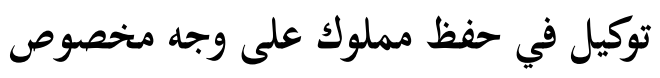

"Represent other people to maintain certain assets in a certain way"3

Furthermore, according to Wahbah Zuhaily wadi'ah derived from the word wada'a means to leave or put something to other people to maintain and maintain. ${ }^{4}$ Etymologically means the property entrusted to someone who is trusted to guard it. Encyclopedia said that Islamic Law is explained In terms of terminology, there are two definitions used by jurisprudents: First the Hanafi School of Ulama defines it by "including other people in maintaining property, both with clear expressions, through piercing or through Signs". The two Maliki, Syafi'i, and Hanbali Scholars define Wadi'ah by "representing others to maintain certain assets in certain ways. ${ }^{5}$

If it is observed from a number of definitions above all the definitions do not substantially show fundamental differences, it's just that there are editorial differences between including and representing. So it can be understood that wadi'ah is giving power to someone who is trusted to maintain certain assets in a certain way. Another definition of wadi'ah is (as agreed between the two parties). So in general it can be concluded that the definition of Al-Wadi'ah can be interpreted as a pure deposit from one party to another, both individuals and legal entities, which must be guarded and returned whenever the requester wants it, or a contract of safekeeping of goods or services between parties have goods or money with a party that is trusted with the aim of maintaining the safety, security and integrity of the goods or money.

\footnotetext{
${ }^{2}$ Nasrun, H. Fiqh Muamalah. (Jakarta: Gaya Media Pratama, 2007), p. 17

${ }^{3}$ Ibnu Hajar al-Haitamy, Tuhfah al Muhtaj, Juz. VI, (Libanon: Darul Fukad, 1997), p. 307.

${ }^{4}$ Wahbah Zuhaily, Al-Uqud al-Musammah fi Qanun al-Mu'amalat.. Damsik: Dar al-Fiqri. 1987. p 297.

${ }^{5}$ PT Ichtiar Batu Van Hoeve, Ensiklopedi Hukum Islam..., p. 1899.
} 


\subsection{Legal Basis of al-Wadi'ah in Islamic Economic Law}

The legal basis or argument that has been agreed upon is the Ulama Law in Islam. There are four basic legal arguments, namely: Al- Qur'an , Al-adis, al-Ijma and al-Qiyas. Associated with the legal basis of the practice of Mua'amalah al-Wadi'ah is contained in the Qur'an, al-hadsi and ijma 'as follows.

1) The legal basis for al-Qaur'an.

In Surat al-Nisa 'verse: 58 explained

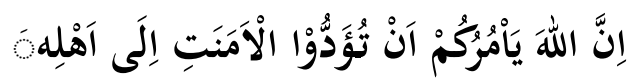

Meaning: "Verily Allah commanded you to deliver the message (entrusted), to those who have the right to receive it". (An-Nisaa: 58)

Furthermore, the qur'an of Surat al-Baqarah verse: 283 which is said:

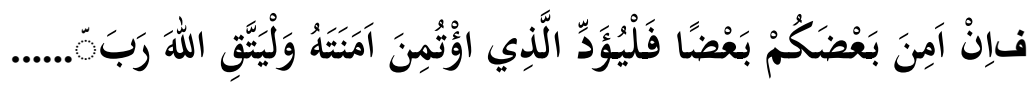

Meaning: "Meaning: If you are on a journey (and do not have cash) while you are not getting a writer, then there should be hold items held [180] (by those who owe). but if some of you trust some of the others, then let that believe fulfill their mandate (debt) and let them fear Allah Allah; and do not (the witnesses) hide the testimony. and whoever hides it, Lo! he is a sinner; and Allah knows what you do. "(Al Baqarah: 283)

In these two verses, meaning dhahir explains and points to two things, the first is the command to preserve and maintain the mandate which can also be interpreted as a deposit, and the second instructs us to fulfill or return manah (a deposit) to expert (the rightful owner).

2) The legal basis for the hadits

There are several traditions which are used as the basis of the law of al-Wadi'ah, that is, among them the words of the Prophet SAW.

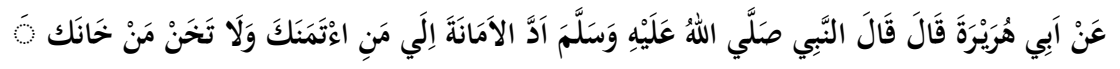

Meaning: Abu Hurairah narrates that the Prophet Muhammad. Saying: "Convey (fulfill) the mandate to those who have the right to receive it and do not repay treason to those who have betrayed you". (H.R. Abu Dawud and according to Tirmidhi the Hadith is hasan, while according to Imam Hakim it categorizes it as valid). ${ }^{6}$

Furthermore the Hadith narrated by Thabrani "from Ibnu Umar said that the Prophet Muhammad SAW. Said, "There is no perfection of the faith of those who are not safe, there is no prayer for those who are not cleansed." 7

3) Legal Basis on Ijma'

Based on the verses and hadith above is ulama agreed to say that the wadi'ah contract is permissible and mandub (disunnahkan) in order to help each other help each other. Therefore

\footnotetext{
${ }^{6}$ Teuku Umar Ash Sidiqy, Koleksi Hadis-Hadis Hukum, (Semarang: Pustaka Rizqi Putra, 2001), p. 238.

${ }^{7}$ Ibid.
} 
Ibn Qudamah (the Hambali school of jurisprudence expert) stated that since the time of the Prophet Muhammad until the next generation, Wadi'ah had become an Ijma amali '(consensus in practice) for Muslims and no ulama had denied it. ${ }^{8}$

So far it can be concluded that the legal basis for the practice of mu'amala al-Wadi'ah in Islamic economic law is based on the Hadith and ijmak al-quran.

\section{Discussion}

An important element in the practice of mu'amalah al-Wadi'ah can be meant for pillars or conditions of al-Wadi'ah, although both conditions and harmony are equally influential for legal law in the practice of wadi'ah, you need to know that the law and conditions have different different mean substances. Next, the speaker tries to touch on a glimpse of the difference. The word rukun comes from the language 'Arabic (al-rukn), meaning the strongest side, then al-rukn al-syai contains the side of something that is a place to rest. Whereas viewed from the terminology aspect of fiqh (fiqh terminology) harmonious is something where something is seen as very decisive for a certain discipline, also it is an integral part of the discipline itself, or in other words harmony is perfecting something where it is part of something that is. ${ }^{9}$

From Muhammad's explanation 'Abid Abdullah al-Kabisi above, it can be understood that the existence of harmony cannot be separated from something that is where he relies, such as reading surat al-fatitah in prayer as one of the pillars for the validity of prayer, and al-Fahihah is also a part from prayer activities. While the conditions in its existence are considered to be decisive for an act, but it is not in a position as part of the action but is separate from the action. For example, cleansing (ber-wudhü) is one of the conditions for the validity of prayer, but the existence of the $w u d h \bar{u}$ is not one of the parts of prayer.

\subsection{Pillars and Conditions of al-Wadi'ah}

As for rukun wadia'h, the figh Ulama disagree in looking at and establishing the pillars of the wadi'ah. Among them look in general and others set in detail. According to Umaer Capra, rukun wadi'ah consists of: the first person who entrusts (al-Muwaddi), the two people entrusted (wadi) 'to the three safekeeping items (wadi'ah), and the four Iqab qabul (Shigat). Whereas the wadi'ah requirements are binding on the parties who are mindful, who entrust the goods (muwaddi ', and who is given (wadi') as well as safekeeping (wadi'ah), and Ijab Qabul (shigat). ${ }^{10}$

\subsection{The Character of Akad in al-Wadi'ah}

Jurisprudence agreed that wadi'ah contract is binding on both parties. If someone is entrusted with goods by someone else and the contract fulfills the pillars and wadi'ah requirements, then the party entrusted is responsible for maintaining the safekeeping item. But whether is the responsibility for maintaining it is a mandate or compensation (Dhamanah). Jurisprudence scholars agree that the status of wadi'ah is trustworthy rather

\footnotetext{
${ }^{8}$ PT Ichtiar BAtu Van Hoeve, Ensiklopedi Hukum Islam, (Jakarta, PT. Internusa, 1997) Jilid 6 page 1899.

${ }^{9}$ Muhamad 'Abid Abdullah al-Kabisi, Ahkam al-Waqf Fi al-Syari'ah al-Islamiyah, penertjemah Ahrul Sani Fathurrahman, Hukum Wakaf Kajian Kontemporer Pertama Dan Terlengkap Tentang Fungsi Dan Pengelolaan Wakaf, (Jakarta: IIMaN, 2003), h, 87.

${ }^{10}$ Wahbah Zuhaily, Al-Uqud al-Musammah fi Qanun al-Mu'amalat... p. 290.
} 
than dhamanah. So they all damage that occurs during the safekeeping of goods is not the responsibility of the person entrusted (wadi). The damage is intentionally done. The rationale is based on the arguments of the Prophet's hadith: the person entrusted with the goods if they do not commit betrayal is not subject to compensation "HR Baihaqi and Daruqutni). ${ }^{11}$

From the above hadith, fiqh scholars agree that if the contract of wadi'ah is required, the person entrusted is subject to compensation for damage to the goods during the deposit, once the damage is not intentional, then wadi'ah contract is canceled. Another consequence of the trustworthiness of wadi'ah contract is that according to ulema fiqh, the party entrusted with the goods may not ask for wages from the safekeeping of goods.

\subsection{Types of wadi'ah}

Mohammad Firdaus in his book Concept and Implementation of Shari'ah Bank divided wadi'ah into two types, namely: First Wadi'ah Yad al-Amanah (trust hand) which means, the contract of safekeeping of goods or money where the recipient of the deposit is not permitted to use the goods or money. ${ }^{12}$ But the person entrusted with the item (wadi ') is not responsible for the loss or damage that occurs to the safekeeping item as long as it is not a result of negligence or carelessness involved in maintaining the safekeeping of goods (for reasons beyond their capabilities). This was stated in a Hadith of the Prophet: "Unsolicited liability guarantees from non-abusing borrowers (loans) and deposit recipients who are not negligent.

The second is Wadi'ah Yad adh Dhamanah. Wadi'ah Yad Dhamanah is a contract of safekeeping of goods or money where the recipient of the deposit with or without the permission of the owner of the goods can utilize the goods or money deposited and must be responsible for the loss or damage of the item. Wadi'ah contract applies if the person entrusted with the goods (Wadi') no longer idles the asset or safekeeping, but uses it in a certain economy after obtaining permission from the person who owns the property (Muwaddi'), thus Wadi contract 'the one who applies is wadi'ah and dhamanah (hands of the guarantor) who are responsible for any damage or loss that occurs to the item. ${ }^{13}$

\subsection{Consequences and Legal Implications of Mu'amalah Al-Wadi'ah}

As mentioned before, that from the elements of wadi'ah both the review of the terms and conditions can affect the consequences or legal application. The following are some details of the influence of the law of Wadi'ah from Yahya Amanah to Yadh Dhamanah caused by several cases, as follows ${ }^{14}$ :

1) The person entrusted does not maintain the safekeeping item. If the deposit is damaged by another person or other possibility that could cause the item to be damaged or lost while he is able to prevent it, then he will be compensated for his negligence.

2) To deny the procedure for maintaining safekeeping. Wadi must compensate if the item is damaged or lost because he violates the agreement on the procedure for maintaining the item. Like, the agreement between Muawaddi 'and Wadi' put the

\footnotetext{
${ }^{11}$ Ibid, h.

12 Mohammad Firdaus, dkk, Konsep dan Implementasi Bank Syari'ah, Yakarta, Renainsan, 2005, h. 36.

${ }^{13}$ Lihat Nail al Author, 5/296, sebagaimana dikutip oleh Muhammad, system dan Prosedur Oprasional Perbankan Syari'ah, (Yogyakarta: UII Press, 2000, h. 8.

${ }^{14}$ Wahbah Zuhaily, Al-Uqud al-Musammah fi Qanun al-Mu'amalat.. Damsik: Dar al-Fiqri. 1987. hal 301- 303
} 
safekeeping items in the cupboard, but Wadi moved it without the knowledge of Muhaddi', so he was compensated for the damage or loss of the item.

3) Leave the deposit to someone else. If the item chosen is damaged or lost because the person entrusted entrusts another person then he must compensate, except in an emergency such as fire or the knowledge of the person who entrusts the item because wadi status (the person entrusted) will move to the person third. According to the scholars of Hanafi and Hambali schools, the person entrusted was subject to compensation, due to the obligation to maintain the item carried on his shoulder. But the number of scholars including Imam Abu Yusuf and Muhammad bin Hasan AshSyaibani (both Hanafi School of Jurisprudence) stated that in such cases the owner of the goods may choose whether he may claim compensation to the person entrusted with the goods (Wadii 'I) so that the person entrusted the goods by the person entrusted first (wadi II) is not subject to compensation. Or he asks for compensation to the person entrusted with the second, but he (wadi II) may request compensation to (wadi I) If the item is damaged or used by (wadi II) in a clear manner so that the owner may ask for compensation to wadi I or wadi II.

4) Using safekeeping items. Wadi'ah is not permitted to use safekeeping without the knowledge of Muhaddi, if it is damaged or lost in the condition of being used then wada is subject to compensation.

5) Traveling with a safekeeping item. According to the number of scholars who differ from Hanifah's opinion, the person entrusted is not allowed to carry the safekeeping items in the journey with the possibility of leaving it to someone who is trusted. If the item is lost or damaged, it must compensate. And if he travels with a deposit because no person is entrusted to safeguard the item, if it is damaged or lost then he is not subject to compensation.

6) Borrowing safekeeping or trading it. If the goods entrusted are traded by Wadii 'without permission from Muawaddi' then he must compensate. while the profits from the trade are according to the Maliki School of the person entrusted (Wadii '). If the business is based on the permission of muwaddi, the contract of wadi'ah changes into a loan agreement. (ad Dain).

7) Mixing deposits with others. Wadii must compensate for the safekeeping if he deliberately interferes with other materials that are difficult to separate.

8) Denies safekeeping. If Muwaddi asked for his possessions and he was not handed over by Wadii, 'then he denies the existence of the contract and the safekeeping, the damage and loss of the item will be borne by Wadii.'

9) Returning safekeeping without permission from Muwaddi. Damage or loss of safekeeping is borne by wadii if he returns without permission and knowledge of muwaddi (damaged or lost at the time of return).

10) According to Abdul Husain at-Tariqi In the wadi'ah yad amanah to be yad Dhamanah, the receipt of the deposit is not responsible for the damage of the goods except in some cases, including, Khianat, not careful, the safekeeping is mixed with other safekeeping, by therefore, the requirement for deposits is that the perpetrator of the transaction is a person who has a sense as well as an adult and the deposit of goods has been received after the handover. ${ }^{15}$

15 Abdul Husain at-Tariqi, alih terjemah oleh M Ifan Syofwani, Ekonomi Islam Prinsp, Dasar, dan tujuan, Yogyakarta, Magistra Insania, 2004. h. 266 


\section{Conclusion}

Definition of wadi'ah, even though there is a diversity of editors in the formulation of the meaning, but substantially does not show fundamental differences, it's just that there are editorial differences between including and representing. So it can be understood that wadi'ah is giving power to someone who is trusted to maintain certain assets in a certain way. The legal basis for Wadiah is found in Qur'an, Surat al-Nisa verse: 58, and Surat al-Baqarah, verse: 283. Besides that, there is also a legal basis in the Hadith, a History of the abi of David, and the ijmak of the scholars. The consequences and legal implications of yadh amanah become yadh dhamanah, or in other languages compensation must occur if and this occurs in wadi'ah yad Dhamanah. First the recipient of the deposit is not responsible for the damage to the item except in a number of cases, including, Khianat, not careful, the safekeeping goods are mixed with other safekeeping items and so on. Second, the change in the status of wadi'ah yad amanah to wadi'ah yad Dhamanah is if the person entrusted does not keep the safekeeping of goods, denies the procedure for the maintenance of safekeeping, entrusts to other people, uses safekeeping, travels with safekeeping, borrows goods deposit or trade it, return the deposited goods without permission from muwaddi ', and deny the deposit.

\section{References}

Abdul Husain at-Tariqi, alih terjemah oleh M Ifan Syofwani, Ekonomi Islam Prinsp, Dasar, dan tujuan, Yogyakarta, Magistra Insania, 2004.

Ibnu Hajar al-Haitamy, Tuhfah al Muhtaj, Juz. VI, (Libanon: Darul Fukad, 1997)

Muhamad 'Abid Abdullah al-Kabisi, Ahkam al-Waqf Fi al-Syari'ah al-Islamiyah, penerjemah Ahrul Sani Fathurrahman, Hukum Wakaf Kajian Kontemporer Pertama Dan Terlengkap Tentang Fungsi Dan Pengelolaan Wakaf, (Jakarta: IIMaN, 2003).

Mohammad Firdaus, dkk, Konsep dan Implementasi Bank Syari'ah, Yakarta, Renainsan, 2005 Muhammad, Nail al Author, 5/296, sebagaimana dikutip oleh Muhammad, system dan Prosedur Oprasional Perbankan Syari'ah, (Yogyakarta: UII Press, 2000.)

Muhammad Syafi'I Antonio, Bank Syari'ah, dari teori ke Praktek, Jakarta, Gema Insani Press, 2001

Muhammad Usman Syabir, al-Muamalat al Maliyah al Mu'asyirah fi al Fiqh al Islami, al Ardan: dar An-Nafa'is, 1998.

Nasrun, H. Fiqh Muamalah. (Jakarta: Gaya Media Pratama, 2007)

PT Ichtiar BAtu Van Hoeve, Ensiklopedi Hukum Islam, Jilid 6, (Jakarta, PT. Internusa, 1997).

Tim Pengembangan Perbankan syari'ah institute banker Indonesia, konsep, produk dan Implementasi Oprasional bank syari'ah, (Jakarta : Djambatan, 2002.

Teuku Umar Ash Sidiqy, Koleksi Hadis-Hadis Hukum, (Semarang: Pustaka Rizqi Putra, 2001).

Wahbah Zuhaily, Al-Uqud al-Musammah fi Qanun al-Mu'amalat. Damsik: Dar al-Fiqri. 1987. 